\title{
Cofilin activation in peripheral CD4 T cells of HIV-I infected patients: a pilot study Yuntao Wu${ }^{* 1}$, Alyson Yoder ${ }^{1}$, Dongyang $\mathrm{Yu}^{1}$, Weifeng Wang ${ }^{1}$, Juan Liu ${ }^{1}$, Tracey Barrett ${ }^{2}$, David Wheeler ${ }^{2}$ and Karen Schlauch ${ }^{3}$
}

Address: ${ }^{1}$ Department of Molecular and Microbiology, George Mason University, Manassas, VA, 20110, USA, ${ }^{2}$ Clinical Alliance For Research \& Education - Infectious Diseases, LLC, Annandale, VA, 22003, USA and ${ }^{3}$ Department of Genetics and Genomics, Boston University School of Medicine, Boston, MA, 02118, USA

Email: Yuntao Wu* - ywu8@gmu.edu; Alyson Yoder - ryoder@gmu.edu; Dongyang Yu - dyu2@gmu.edu; Weifeng Wang - wwangb@gmu.edu; Juan Liu - jliug@gmu.edu; Tracey Barrett - tbarrett@careidresearch.com; David Wheeler - dwheel423@verizon.net;

Karen Schlauch - schlauch@bu.edu

* Corresponding author

Published: 17 October 2008

Retrovirology 2008, 5:95 doi:10.1/86/1742-4690-5-95

This article is available from: http://www.retrovirology.com/content/5/I/95

(C) $2008 \mathrm{Wu}$ et al; licensee BioMed Central Ltd.

This is an Open Access article distributed under the terms of the Creative Commons Attribution License (http://creativecommons.org/licenses/by/2.0), which permits unrestricted use, distribution, and reproduction in any medium, provided the original work is properly cited.
Received: 9 September 2008

Accepted: 17 October 2008

\begin{abstract}
Cofilin is an actin-depolymerizing factor that regulates actin dynamics critical for $T$ cell migration and $\mathrm{T}$ cell activation. In unstimulated resting CD4 T cells, cofilin exists largely as a phosphorylated inactive form. Previously, we demonstrated that during HIV-I infection of resting CD4 T cells, the viral envelope-CXCR4 signaling activates cofilin to overcome the static cortical actin restriction. In this pilot study, we have extended this in vitro observation and examined cofilin phosphorylation in resting CD4 T cells purified from the peripheral blood of HIV-I-infected patients. Here, we report that the resting $T$ cells from infected patients carry significantly higher levels of active cofilin, suggesting that these resting cells have been primed in vivo in cofilin activity to facilitate HIV-I infection. HIV-I-mediated aberrant activation of cofilin may also lead to abnormalities in $\mathrm{T}$ cell migration and activation that could contribute to viral pathogenesis.
\end{abstract}

\section{Findings}

Cofilin is a member of the actin-depolymerizing factor (ADF) family of proteins [1] that play a central role in regulating actin dynamics $[2,3]$. The actin-severing and depolymerization activities of cofilin are essential in controlling cell polarity [4], cell motility [5] and cell division $[6,7]$. In the human immune system, cofilin has also been implicated in two hallmark activities of $\mathrm{T}$ cells, namely chemotaxis and $\mathrm{T}$ cell activation [8]. In chemotaxis, directed cell movement towards chemoattractants is controlled by localized cortical actin polymerization and depolymerization, and cofilin is the driving force for promoting the cortical actin dynamics [9]. In antigen-specific $\mathrm{T}$ cell activation the reorganization of the cortical actin plays a critical role in the formation of the immunological synapse. Engagement of CD2 or CD28 receptors but not TCR results in cofilin activation and its association with the actin cytoskeleton [10]. Peptides that block cofilin binding to actin result in severe defects in $\mathrm{T}$ cell activation [11].

Cofilin activity is regulated through phosphorylation and dephosphorylation at serine-3 by the simultaneous actions of cofilin kinases and phosphatases [12-14]. Phosphorylated cofilin is unable to bind to F-actin; thus cofilin is inactivated by phosphorylation and activated by dephosphorylation $[13,14]$. The direct upstream kinases that inactivate cofilin are the LIM kinases (LIMK1 and 
LIMK2) $[15,16]$, whereas several serine phosphatases such as slingshot, chronophin $[17,18], \mathrm{PP} 1 \alpha$ and PP2A [19] dephosphorylate and activate cofilin.

Recently, we [20] and others [21] have demonstrated that in unstimulated resting CD4 $\mathrm{T}$ cells purified from the peripheral blood, cofilin exists largely as the phosphorylated form, implying that in the absence of chemotactic stimulation or T cell activation, cofilin is largely inactive. We have also suggested that this restricted cofilin activity in resting $\mathrm{T}$ cells inhibits the cortical actin dynamics, hindering viral post-entry migration. Thus, HIV-1 hijacks chemokine receptor signalling through CXCR4 to trigger the activation of cofilin. This process increases the cortical actin dynamics, facilitating viral nuclear migration $[20,22]$.

Given the fact that in infected patients, CD4 T cells are chronically exposed to gp 120 , we decided to investigate the outcome of persistent gp120 stimulation on cofilin phosphorylation. To address this question, we initially used resting CD4 $\mathrm{T}$ cells purified from HIV negative donors and stimulated them with HIV-1 or gp120 for extended periods of time. We incubated cells with the virus for several hours up to 24 hours instead of minutes. Persistent stimulation of a receptor has been known to affect down-stream targets differently than transient stimulation [23]. As shown in Figure 1A, we observed cycles of cofilin phosphorylation and dephosphorylation with the prolonged treatment. These data suggest that persistent stimulation with HIV will likely have a lasting impact on the cofilin activity. We also repeated this experiment using purified gp120 and observed persistent cofilin dephosphorylation (Figure 1B). The variation in cofilin responses between HIV particles and gp120 may be related to differences in dosage or gp 120 conformation. HIV particles carry the gp120 trimer on the surface, whereas the purified gp120 protein we used is a monomer. This is reminiscent of the CD40 ligand (CD40L) in its distinctive signalling properties as a trimer or as a monomer [24]. The strength and persistence of CD40L stimulation dictate the capacity of dendritic cells either to migrate to draining lymph nodes or to secrete locally inflammatory cytokines [24].

Based on these results, we also hypothesized that activation of cofilin may also occur in the resting CD4 T cells of HIV-1-infected patients, considering that these resting T cells are chronically exposed to gp 120 during the course of infection, and that even in patients on HAART, latently infected cells persist and low levels of viral replication take place [25-27]. Additionally, the threshold for coreceptor activation of signalling has been shown to be as few as two HIV virion particles [28]. Thus, we set up a small-scale pilot study to probe cofilin activity in resting cells purified from HIV-1-infected and uninfected subjects. Peripheral

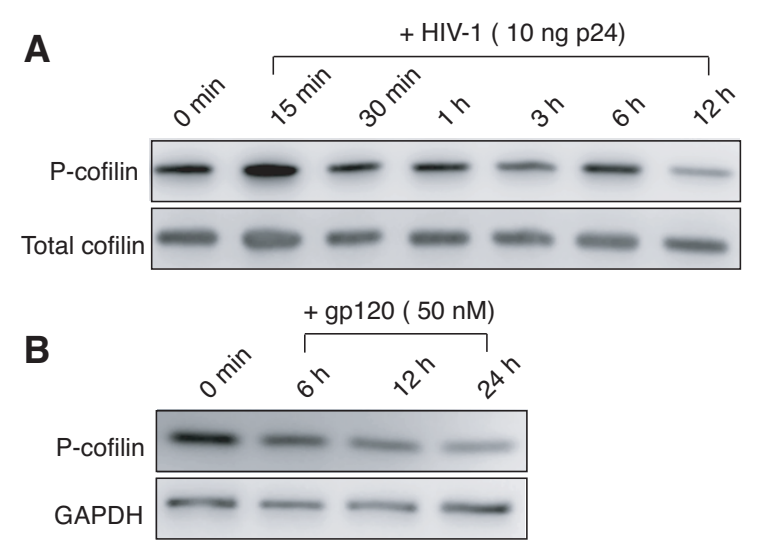

Figure I

Activation of cofilin in resting CD4 T cells cultured in vitro and stimulated with HIV-I and gp I 20. Resting CD4 T cells were purified from uninfected donors by antibody-mediated negative depletion using Dynalbeads as previously described [20]. Cells were cultured overnight in the absence of cytokines or activation, and then stimulated with HIV-I (I0 ng p24) (A) or with gPI 20 (50 nM) for various times at $37^{\circ} \mathrm{C}$ as indicated. Stimulated cells were lysed and analyzed by western blot using antibodies against the phosphorylated cofilin (P-cofilin) or total cofilin or GAPDH for controls.

blood resting CD4 T cells from eight infected (Additional file 1) and ten uninfected subjects were purified by negative depletion, unstimulated and then analyzed by immunoblotting for both phospho-cofilin and total cofilin. As shown in Figure 2, in the resting CD4 T cells of uninfected subjects, cofilin exists primarily in its inactive phosphorylated form in the absence of chemotactic stimulation or $\mathrm{T}$ cell activation $[20,21]$ (Figure $2 \mathrm{C}$ ). In contrast, in HIV positive patients, significantly lower ratios of phosphocofilin to total cofilin $\left(\mathrm{HIV}^{-}, 1.142 ; \mathrm{HIV}^{+}, 0.535 ; p=\right.$ 0.002 ) (Figures 2A and Figure 2B) were observed, suggesting a significant shift towards cofilin activation. These results were further confirmed by NEPHGE-western blot to measure the absolute ratio of phospho-cofilin to active cofilin (Figures 2C, Figure 2D). Again, we observed considerably lower ratios of phospho-cofilin to active cofilin in HIV-1-infected patients, confirming the upregulation of cofilin activity in resting CD4 T cells of HIV-1-infected patients. Given the great extent of cofilin activation and the fact that a majority of resting CD4 T cells in patients are not infected (0.2-16.4 HIV-latently infected cells per $10^{6}$ resting CD4 T cells [29]), these data imply a global activation of cofilin in resting CD4 T cells, not just those infected by HIV-1. Therefore, indirect mechanisms, such as contact with viral or cell-free gp120 or chronic immune 
A

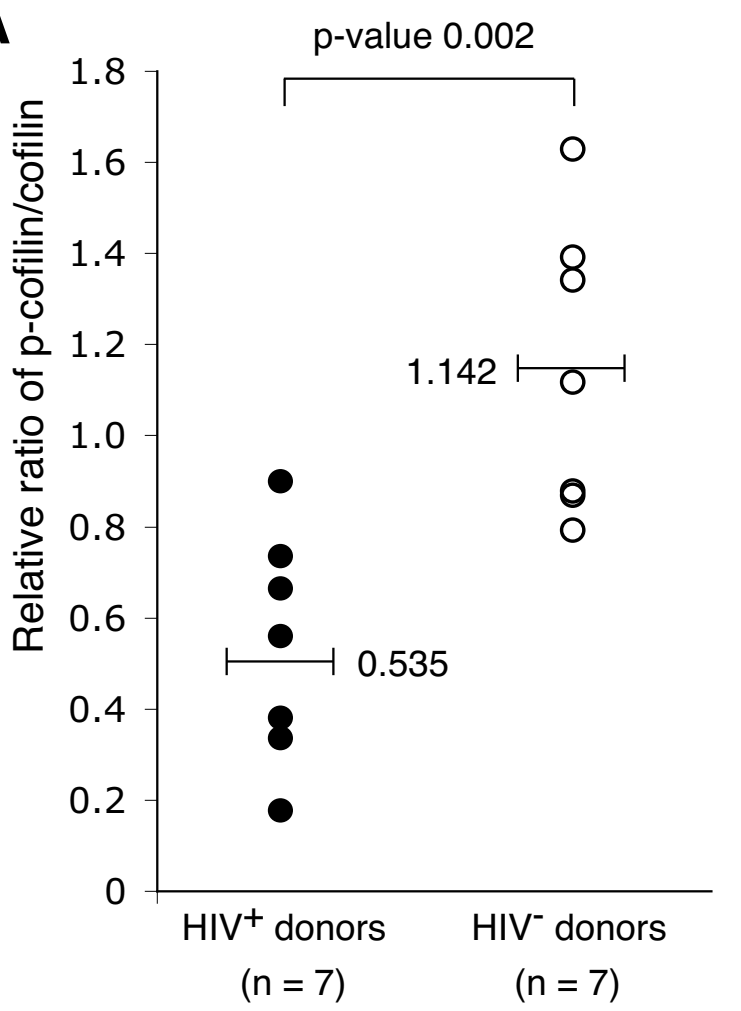

C

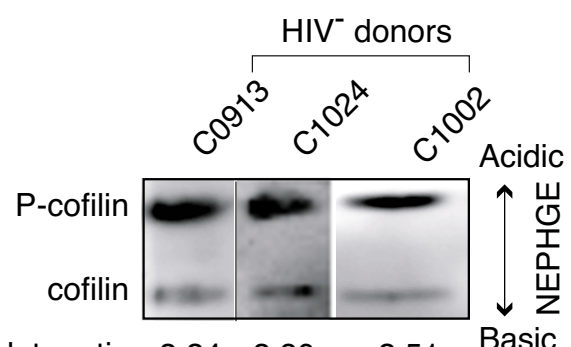

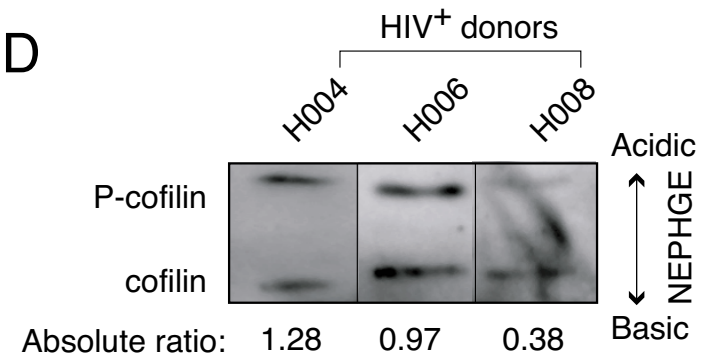

B $\mathrm{HIV}^{+}$donors $\mathrm{HIV}^{-}$donors $\mathrm{HIV}^{+}$donors

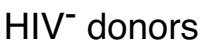
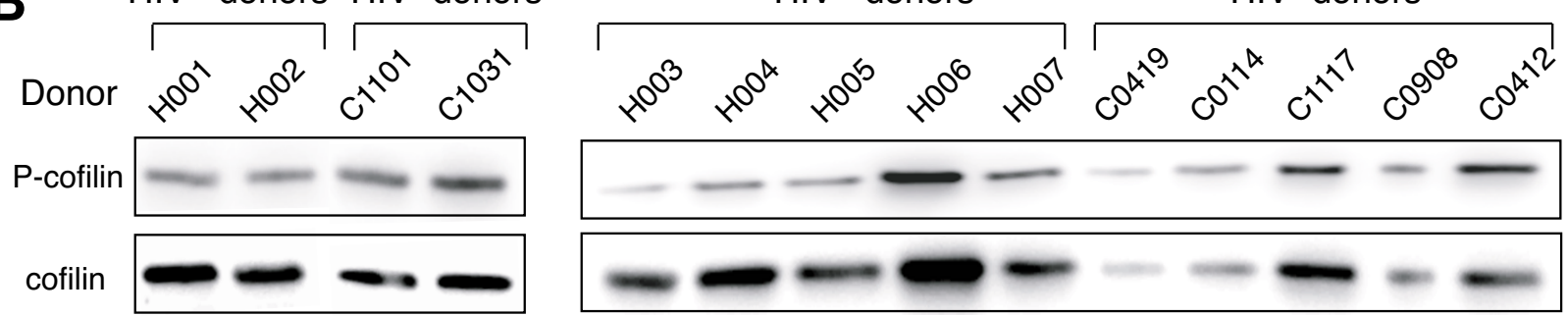

\section{Figure 2}

Activation of cofilin in resting CD4 T cells of HIV-I-infected patients. (A) Resting CD4 T cells were purified by antibody-mediated negative depletion using Dynalbeads. Cells purified from HIV-I-infected and uninfected donors were cultured overnight in the absence of cytokines or activation, and then lysed and analyzed by western blot using antibodies against P-cofilin or total cofilin. The relative ratios of P-cofilin to total cofilin were measured and plotted. HIV-I-infected patients had statistically-significant lower ratios of P-cofilin/cofilin ( 0.535 versus I.I42, $p=0.002)$, suggesting higher levels of active cofilin. For statistic analysis, a two-tailed Student's t-test on the means resulted in a $p$-value of $p=0.002$. At a pre-determined significance level of 0.05 , this shows that the difference in the mean ratios of the two sample groups is statistically significant. A standard power computation showed that the t-test was very well powered (95.2\%) for this study. (B) Shown are the longer exposures of the western blots used in (A). The results were confirmed by NEPHGE-western blot to directly separate P-cofilin to active cofilin, and then probed with an anti-cofilin antibody [20]. Shown are the absolute ratios of P-cofilin to active cofilin in HIV-I negative donors (C) and HIV-I-infected donors (D). 
activation, may be responsible for the activation of cofilin in resting CD4 T cells in patients. Importantly, the cofilin activation observed is not a result of general T cell activation, since the population of CD4 T cells purified from patients is quiescent, judged by the lack of activation markers such as HLA-DR or CD69 on the cell surface (Figure 3), similar to a previous observation [30]. This also appears to be consistent with our previous demonstration that although stimulation with gp120 can trigger cofilin activation, it does not activate resting $\mathrm{T}$ cells [20]. Our data also demonstrate that in the peripheral blood of infected patients, resting CD4 $\mathrm{T}$ cells have largely been altered or primed, at least in cofilin activity, to facilitate HIV-1 infection. Nevertheless, the small patient population as well as lack of multiple controls and long-term follow up studies did not permit us to conclude that the cofilin activation observed is necessarily the result of chronic gp120 exposure, although gp120 has a demonstrated ability to trigger cofilin activation in vitro [20]. Further large-scale studies are needed to address this correlation and other critical questions such as the possible relationship between cofilin activation and disease progression. Future studies are also required to determine whether the status of cofilin correlates with drug treatment. Our previous in vitro study [20] and this small-scale pilot investigation certainly serve as a rationale for future clinical studies.

HIV-1-mediated aberrant activation of cofilin in resting CD4 $\mathrm{T}$ cells may affect normal $\mathrm{T}$ cell migration and $\mathrm{T}$ cell activation. In the human immune system, cofilin is directly involved in chemotaxis and $\mathrm{T}$ cell activation. For
A

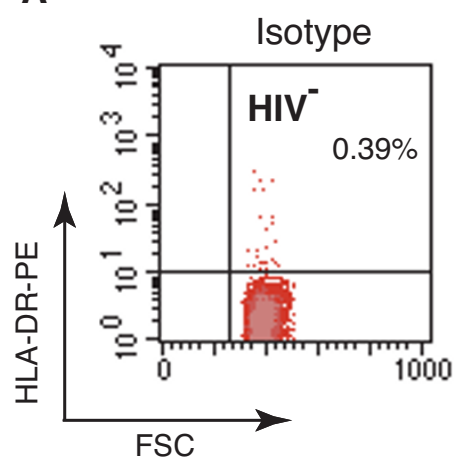

C

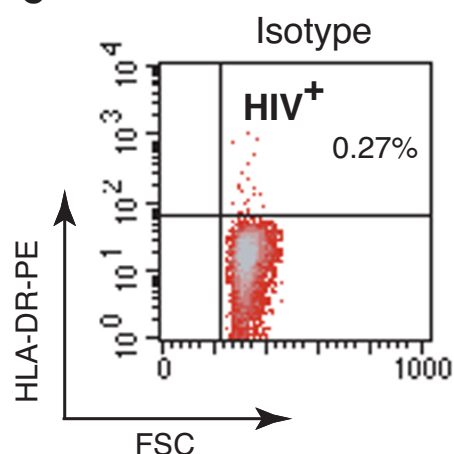

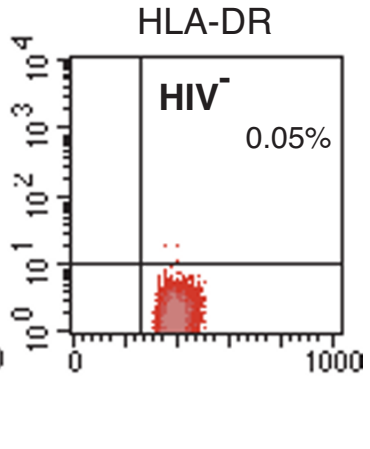

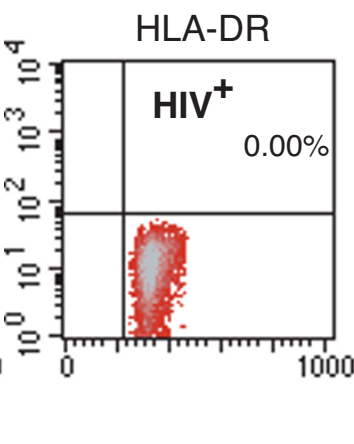

B

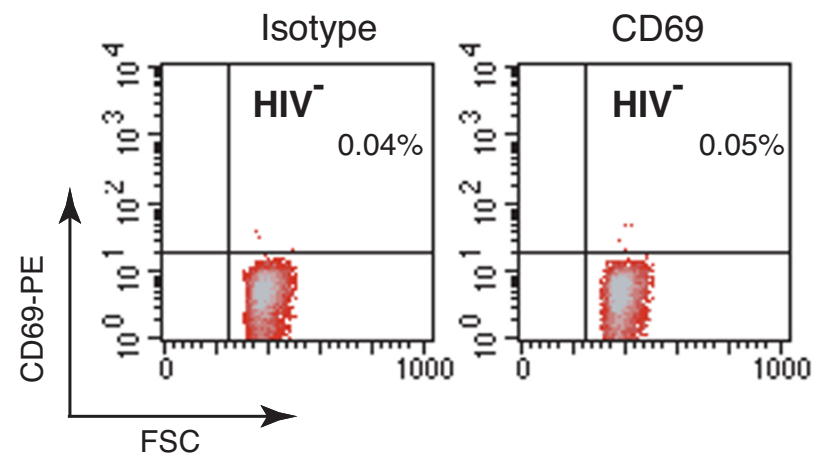

D
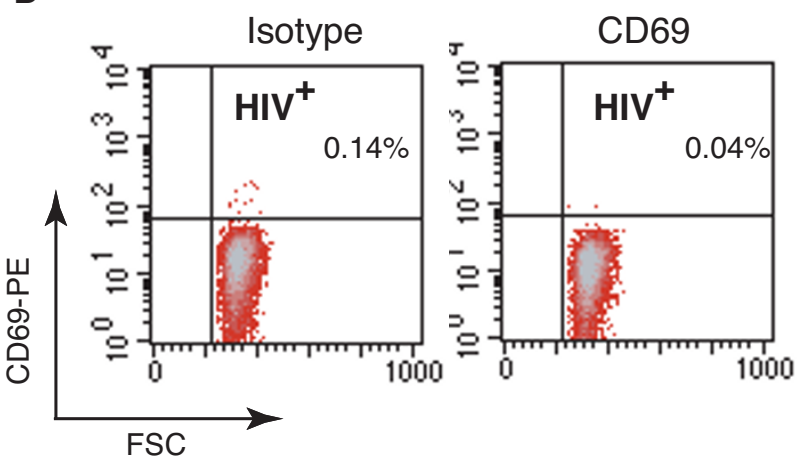

Figure 3

Lack of detection of $\mathrm{T}$ cell activation markers on the surface of resting CD4 T cells from HIV-I-infected and uninfected donors. Resting CD4 T cells were purified by antibody-mediated negative depletion using Dynalbeads. Cells purified from HIV-I-infected and uninfected donors were cultured overnight in the absence of cytokines or activation, and then stained for surface expression of HLA-DR or CD69. Shown are flow cytometry analyses of cells stained with a PE-labelled antihuman HLA-DR antibody (A and C, right panel) or a similarly labelled isotype control antibody (A and C, left panel). Cells were also stained with a PE-labelled anti-human CD69 antibody (B and D, right panel) or a similarly labelled isotype control antibody ( $B$ and $D$, left panel). Cells from the HIV negative donor (HIV-) were used in (A) and (B), and cells from the HIV-I-infected donor $\left(\mathrm{HIV}^{+}\right)$were used in (C) and (D). 
example, cofilin was shown to affect SDF1 $\alpha$-driven T cell chemotaxis, and blocking cofilin phosphorylation diminishes actin reorganization and normal chemotactic response [9]. During T cell activation, cofilin is activated by co-stimulation signals to mediate cortical actin reorganization, which plays a critical role in the formation and stabilization of the immunological synapse. It is commonly known that genetic defects affecting actin activity by means of a deficiency in signaling molecules, such as WASP, cause immunodeficiency [31,32]. It would not be a surprise if cofilin dysregulation also results in $\mathrm{T}$ cellmediated immunodeficiencies, given the central role of cofilin in regulating actin dynamics in T cells [33].

The demonstration of cofilin activation in resting CD4 T cells of HIV-1-infected patients offers new avenues for investigation into viral pathogenesis. It has long been recognized that the residual CD4 T cells in HIV-1-infected patients have numerous functional abnormalities, such as loss of $\mathrm{T}$ helper function [34], T cell anergy [35,36], increased $\mathrm{T}$ cell proliferation [37] and abnormal $\mathrm{T}$ cell homing and migration $[38,39]$. These $\mathrm{T}$ cell defects largely result from a bystander effect [40]. It remains to be determined whether some of these abnormalities are directly linked to aberrant activation of cofilin in resting CD4 T cells. Additionally, as shown in this pilot study, the peripheral CD4 T cells in HIV-1 patients strikingly resemble the migratory $\mathrm{T}$ lymphoma cells in terms of carrying active cofilin $[21,41]$. It is likely that these CD4 T cells also have abnormal migratory behaviours associated with aberrant cofilin activation. It remains unknown whether migratory abnormalities could contribute to the eventual destruction of $\mathrm{T}$ cells in lymph nodes or tissues. Finally, the identification of cofilin as a critical molecule in resting CD4 T cells of infected patients may serve as a diagnostic marker to reflect alterations of $\mathrm{T}$ cell function in disease progression.

\section{Abbreviations}

LIMK1: LIM Domain Kinase 1; TCR: T Cell Receptor; HAART: Highly Active Antiretroviral Therapy; NEPHGE: Nonequilibrium pH Gel Electrophoresis; HLA-DR: Human Leukocyte Antigen-DR; WASP: Wiskott-Aldrich Syndrome Protein; SDF1 $\alpha$ : Stromal-Cell-Derived Factor $1 \alpha$.

\section{Competing interests}

The authors declare that they have no competing interests.

\section{Authors' contributions}

YW conceived of the study, supervised blood donation, performed $\mathrm{T}$ cell purification and wrote the manuscript. AY, DY, WW, and JL performed cell purification, western blot, and analysis. TB and DW supervised HIV+ donor recruiting and testing. KS performed statistical analyses.

\section{Additional material}

\author{
Additional file 1
}

Click here for file

[http://www.biomedcentral.com/content/supplementary/17424690-5-95-S1.pdf]

\section{Acknowledgements}

We thank the George Mason University (GMU) Student Health Center and the GMU and Chesapeake Bay Institutional Review Boards. AY was supported by the National Defense Science and Engineering Fellowship. This work was supported by GMU and by Public Health Service grant A106998I from NIAID to YW.

\section{References}

I. Bamburg JR, Harris HE, Weeds AG: Partial purification and characterization of an actin depolymerizing factor from brain. FEBS Lett 1980, I21:178-182

2. Lappalainen $P$, Drubin DG: Cofilin promotes rapid actin filament turnover in vivo. Nature 1997, 388:78-82.

3. Bamburg JR: Proteins of the ADF/cofilin family: essential regulators of actin dynamics. Annu Rev Cell Dev Biol 1999, 15:185-230.

4. Dawe HR, Minamide LS, Bamburg JR, Cramer LP: ADF/cofilin controls cell polarity during fibroblast migration. Curr Biol 2003, 13:252-257.

5. Carlier MF, Laurent V, Santolini J, Melki R, Didry D, Xia GX, Hong Y, Chua NH, Pantaloni D: Actin depolymerizing factor (ADF/cofilin) enhances the rate of filament turnover: implication in actin-based motility. J Cell Biol 1997, I 36: I307-I 322.

6. Lee YJ, Keng PC: Studying the effects of actin cytoskeletal destabilization on cell cycle by cofilin overexpression. Mol Biotechnol 2005, 31:I-I0.

7. Abe H, Obinata T, Minamide LS, Bamburg JR: Xenopus laevis actindepolymerizing factor/cofilin: a phosphorylation-regulated protein essential for development. J Cell Biol 1996, I 32:87 I-885.

8. Samstag Y, Eibert SM, Klemke M, Wabnitz GH: Actin cytoskeletal dynamics in T lymphocyte activation and migration. J Leukoc Biol 2003, 73:30-48.

9. Nishita M, Aizawa $H$, Mizuno K: Stromal cell-derived factor I alpha activates LIM kinase I and induces cofilin phosphorylation for T-cell chemotaxis. Mol Cell Biol 2002, 22(3):774-783.

10. Lee KH, Meuer SC, Samstag Y: Cofilin: a missing link between T cell co-stimulation and rearrangement of the actin cytoskeleton. Eur J Immunol 2000, 30:892-899.

II. Eibert SM, Lee KH, Pipkorn R, Sester U, Wabnitz GH, Giese T, Meuer SC, Samstag Y: Cofilin peptide homologs interfere with immunological synapse formation and $\mathbf{T}$ cell activation. Proc Natl Acad Sci USA 2004, I 0 I: 1957-1962.

12. Morgan TE, Lockerbie RO, Minamide LS, Browning MD, Bamburg JR: Isolation and characterization of a regulated form of actin depolymerizing factor. I Cell Biol 1 993, 1 22:623-633.

13. Agnew BJ, Minamide LS, Bamburg JR: Reactivation of phosphorylated actin depolymerizing factor and identification of the regulatory site. J Biol Chem 1995, 270: 17582-17587.

14. Rosenblatt J, Agnew BJ, Abe H, Bamburg JR, Mitchison TJ: Xenopus actin depolymerizing factor/cofilin (XAC) is responsible for the turnover of actin filaments in Listeria monocytogenes tails. J Cell Biol 1997, 136:1323-1332.

15. Yang N, Higuchi O, Ohashi K, Nagata K, Wada A, Kangawa K, Nishida E, Mizuno K: Cofilin phosphorylation by LIM-kinase I and its role in Rac-mediated actin reorganization. Nature 1998, 393:809-812

16. Arber S, Barbayannis FA, Hanser H, Schneider C, Stanyon CA, Bernard O, Caroni P: Regulation of actin dynamics through phosphorylation of cofilin by LIM-kinase. Nature 1998, 393:805-809. 
17. Niwa R, Nagata-Ohashi K, Takeichi M, Mizuno K, Uemura T: Control of actin reorganization by Slingshot, a family of phosphatases that dephosphorylate ADF/cofilin. Cell 2002, 1 08:233-246.

18. Gohla A, Birkenfeld J, Bokoch GM: Chronophin, a novel HADtype serine protein phosphatase, regulates cofilin-dependent actin dynamics. Nat Cell Biol 2005, 7:21-29.

19. Ambach A, Saunus J, Konstandin M, Wesselborg S, Meuer SC, Samstag $Y$ : The serine phosphatases PPI and PP2A associate with and activate the actin-binding protein cofilin in human $T$ lymphocytes. Eur J Immunol 2000, 30:3422-343I.

20. Yoder A, Yu D, Dong L, lyer SR, Xu X, Kelly J, Liu J, Wang W, Vorster PJ, Stephany DA, et al.: HIV envelope-CXCR4 signaling activates cofilin to overcome cortical actin restriction in resting CD4 T cells. Cell 2008, I34:782-792.

21. Samstag Y, Eckerskorn C, Wesselborg S, Henning S, Wallich R, Meuer SC: Costimulatory signals for human $T$-cell activation induce nuclear translocation of pp I9/cofilin. Proc Natl Acad Sci USA 1994, 9 1:4494-4498.

22. Bukrinsky M: How to engage Cofilin. Retrovirology 2008, 5:85.

23. Poppers DM, Schwenger P, Vilcek J: Persistent tumor necrosis factor signaling in normal human fibroblasts prevents the complete resynthesis of I kappa B-alpha. J Biol Chem 2000, 275:29587-29593.

24. Luft T, Maraskovsky E, Schnurr M, Knebel K, Kirsch M, Gorner M, Skoda $R$, Ho AD, Nawroth $P$, Bierhaus A: Tuning the volume of the immune response: strength and persistence of stimulation determine migration and cytokine secretion of dendritic cells. Blood 2004, 104:1066-1074.

25. Ramratnam B, Mittler JE, Zhang L, Boden D, Hurley A, Fang F, Macken CA, Perelson AS, Markowitz M, Ho DD: The decay of the latent reservoir of replication-competent HIV-I is inversely correlated with the extent of residual viral replication during prolonged anti-retroviral therapy. Nat Med 2000, 6:82-85.

26. Ramratnam B, Ribeiro R, He T, Chung C, Simon V, Vanderhoeven J, Hurley A, Zhang L, Perelson AS, Ho DD, Markowitz M: Intensification of antiretroviral therapy accelerates the decay of the HIV-I latent reservoir and decreases, but does not eliminate, ongoing virus replication. J Acquir Immune Defic Syndr 2004, 35:33-37.

27. Zhu T, Muthui D, Holte S, Nickle D, Feng F, Brodie S, Hwangbo Y, Mullins Il, Corey L: Evidence for human immunodeficiency virus type I replication in vivo in CDI4(+) monocytes and its potential role as a source of virus in patients on highly active antiretroviral therapy. J Virol 2002, 76:707-7I6.

28. Melar M, Ott DE, Hope TJ: Physiological levels of virion-associated human immunodeficiency virus type I envelope induce coreceptor-dependent calcium flux. J Virol 2007, 8 I: |773-| 785.

29. Finzi D, Hermankova M, Pierson T, Carruth LM, Buck C, Chaisson RE, Quinn TC, Chadwick K, Margolick J, Brookmeyer R, et al.: Identification of a reservoir for HIV-I in patients on highly active antiretroviral therapy [see comments]. Science 1997, 278: $1295-1300$.

30. Kinter AL, Umscheid CA, Arthos J, Cicala C, Lin Y, Jackson R, Donoghue E, Ehler L, Adelsberger J, Rabin RL, Fauci AS: HIV envelope induces virus expression from resting CD4+ $\mathrm{T}$ cells isolated from HIV-infected individuals in the absence of markers of cellular activation or apoptosis. J Immunol 2003, I 70:2449-2455.

31. Derry JM, Ochs HD, Francke $U$ : Isolation of a novel gene mutated in Wiskott-Aldrich syndrome. Cell I994, 78:635-644.

32. Symons M, Derry JM, Karlak B, Jiang S, Lemahieu V, McCormick F, Francke $U$, Abo A: Wiskott-Aldrich syndrome protein, a novel effector for the GTPase CDC42Hs, is implicated in actin polymerization. Cell 1996, 84:723-734.

33. Bamburg JR, Wiggan OP: ADF/cofilin and actin dynamics in disease. Trends Cell Biol 2002, I 2:598-605.

34. Clerici M, Stocks NI, Zajac RA, Boswell RN, Lucey DR, Via CS, Shearer GM: Detection of three distinct patterns of $T$ helper cell dysfunction in asymptomatic, human immunodeficiency virus-seropositive patients. Independence of CD4+ cell numbers and clinical staging. J Clin Invest 1989, 84: I892-I899.

35. Gurley RJ, Ikeuchi K, Byrn RA, Anderson K, Groopman JE: CD4+ lymphocyte function with early human immunodeficiency virus infection. Proc Natl Acad Sci USA 1989, 86:1993-1997.

36. Masci AM, Galgani M, Cassano S, De Simone S, Gallo A, De Rosa V, Zappacosta S, Racioppi L: HIV-I gp I 20 induces anergy in naive
T lymphocytes through CD4-independent protein kinase-Amediated signaling. J Leukoc Biol 2003, 74: I I I7-I I 24.

37. Lempicki RA, Kovacs JA, Baseler MW, Adelsberger JW, Dewar RL, Natarajan V, Bosche MC, Metcalf JA, Stevens RA, Lambert LA, et al.: Impact of HIV-I infection and highly active antiretroviral therapy on the kinetics of CD4+ and CD8+ $T$ cell turnover in HIV-infected patients. Proc Natl Acad Sci USA 2000, 97:13778-13783.

38. Chen JJ, Cloyd MW: The potential importance of HIV-induction of lymphocyte homing to lymph nodes. Int Immunol I999, II:1591-1594.

39. Brainard DM, Tharp WG, Granado E, Miller N, Trocha AK, Ren XH Conrad B, Terwilliger EF, Wyatt R, Walker BD, Poznansky MC: Migration of antigen-specific $T$ cells away from CXCR4-binding human immunodeficiency virus type I gp I 20. J Virol 2004, 78:5184-5193.

40. Tough DF, Borrow P, Sprent J: Induction of bystander T cell proliferation by viruses and type I interferon in vivo. Science 1996, 272:1947-1950.

4I. Samstag Y, Dreizler EM, Ambach A, Sczakiel G, Meuer SC: Inhibition of constitutive serine phosphatase activity in $T$ lymphoma cells results in phosphorylation of pp/9/cofilin and induces apoptosis. J Immunol 1996, I 56:4167-4I73.
Publish with Biomed Central and every scientist can read your work free of charge

"BioMed Central will be the most significant development for disseminating the results of biomedical research in our lifetime. "

Sir Paul Nurse, Cancer Research UK

Your research papers will be:

- available free of charge to the entire biomedical community

- peer reviewed and published immediately upon acceptance

- cited in PubMed and archived on PubMed Central

- yours - you keep the copyright

Submit your manuscript here:

http://www.biomedcentral.com/info/publishing_adv.asp
BioMedcentral 